\title{
Implementation of Quality by Design Methodology in Development and Validation of a New Stability- Indicating, Reverse Phase High-Performance Liquid Chromatography Method for the Rapid Estimation of Piribedil in Piribedil Prolonged Release Tablets
}

\author{
N. KUMAR ${ }^{1, *}$, D SANGEETHA ${ }^{1}$, S. J. REDDY AND L. KALAYANARAMAN
}

Department of Analytical Research and Development, Integrated Product Development Organization (IPDO), Dr. Reddy's Laboratories, Hyderabad 500072, ${ }^{1}$ Department of Chemistry, School of Advanced Sciences. Vellore Institute of Technology (VIT), Vellore, Tamil Nadu 632014, India

Kumar et al.: Quality by Design based Reverse Phase High-Performance Liquid Chromatography Method for Assay of Piribedil in Tablets

\begin{abstract}
Piribedil is a diazinane compound used in the treatment of Parkinson's disease. The objective of the current work was to develop a Quality by design based, stability-indicating high-performance liquid chromatography method, with a short runtime to estimate assay in piribedil prolonged release tablets. The assay is an important critical quality attribute of the drug product, which ensures its efficacy. The critical quality attributes were identified and the quality target method profile was defined. Basis of the initial risk assessment, the separation between piribedil and known/unknown degradation products and the sample preparation procedure's robustness were considered critical factors. Phosphate buffer with $0.01 \%$ triethylamine $(\mathrm{pH} 2.5 ; 50 \mathrm{mM})$ and acetonitrile $(80: 20, \mathrm{v} / \mathrm{v})$ were used as mobile phase. The peaks were resolved using Hypersil gold $\mathrm{C} 18,(4.6 \times 150) \mathrm{mm}, 5 \mu \mathrm{m}$ column within a runtime of $5 \mathrm{~min}$. The mobile phase was pumped at a flow rate of $1.3 \mathrm{ml} / \mathrm{min}$, whereas the column was maintained at $30^{\circ}$. A $5 \mu \mathrm{l}$ aliquot of each solution was injected and the peak responses were recorded at $238 \mathrm{~nm}$. The critical chromatographic parameters and sample preparation steps were optimized by using Design of experiments and based on its outcome, method operable design ranges were demarcated. An extensive forced degradation study was executed and all the degradant peaks were well separated from the piribedil peak. Piribedil peak was also found homogenous in all the stressed samples. The developed method was validated and found specific, precise, linear, accurate, rugged and robust.
\end{abstract}

Key words: Quality by design, piribedil, assay, design of experiments, high-performance liquid chromatography, stability indicating

Piribedil is used for treating Parkinson's disease and belongs to the chemical class of diazinane, i.e., sixmembered saturated heterocyclic having four carbon and two nitrogen atoms. It is available as a prolongedrelease tablet in $50 \mathrm{mg}$ strength. Piribedil is approved in European countries such as Germany and France, under the brand name Clarium and Trivastal retard, respectively. It is also beneficial for treating chronic pathological cognitive and neurosensory deficits in aged patients. Piribedil can be represented chemically as 2-[4-(1,3-benzodioxol-5-ylmethyl) piperazin-1-yl] pyrimidine ${ }^{[1,2]}$.

*Address for correspondence

E-mail: nitink@drreddys.com

January-February 2022
Drug efficacy and safety are the two mainstays of drug therapy. The drug's safety is assessed by characterizing the impurities in drug products, whereas the efficacy of the drug is influenced by the drug content present in the pharmaceutical dosage form. The drug product's potency/strength is denoted as the amount of drug

This is an open access article distributed under the terms of the Creative Commons Attribution-NonCommercial-ShareAlike 3.0 License, which allows others to remix, tweak, and build upon the work non-commercially, as long as the author is credited and the new creations are licensed under the identical terms

Accepted 20 February 2022

Revised 07 July 2021

Received 02 January 2021

Indian J Pharm Sci 2022;84(1):207-218 
substance in each dosage unit (assay). The assay estimation is an essential aspect of drug analysis during the batch release and stability studies. It is one of the parameters that help define the shelf life, storage condition and packaging configuration of the drug product $^{[3]}$. The key requirement of the assay method is that it should be stability-indicating.

An extensive survey revealed that piribedil prolongedrelease tablets are not official in pharmacopeia ${ }^{[4,5]}$. Rohith et al. reported a Reverse Phase HighPerformance Liquid Chromatography (RP-HPLC) method to estimate piribedil in bulk drug ${ }^{[6]}$. Ibrahim et al. published potentiometric methodologies for quantifying piribedil in pharmaceutical preparations and urine ${ }^{[7,8]}$. The liquid chromatography methods for estimating piribedil and its metabolite in plasma were also reported ${ }^{[9,10]}$. An analytical method for estimating piribedil in pharmaceutical formulations by micellar electrokinetic capillary chromatography was also published ${ }^{[11]}$. In addition to these analytical methods, few more research articles are reported for formulation development and dissolution enhancement ${ }^{[12-15]}$. However, these analytical methods are not suitable for estimating the assay of piribedil in the formulated tablet dosage form.

Mohan et al. reported an assay estimation method of piribedil in the finished dosage form ${ }^{[16]}$. Basis a careful review of the reported analytical method, we observed that the method's specificity was not ensured by injecting the major known degradation products to rule out any coelution with the parent compound (piribedil). The reported methodology involves tablet crushing for sample preparation, which is prone to error due to improper crushing. Piribedil is a prolonged-release tablet having release controlling polymers, which makes the drug extraction process difficult. Therefore, the robustness of sample preparation is essential to avoid day-to-day variations during the method's actual usage, which was not demonstrated in the reported method.

Thus, the necessity was felt to develop a stabilityindicating HPLC method which can overcome the limitations of the reported analytical methods. The existing work's target was to develop a stabilityindicating RP-HPLC method with a short runtime to determine the assay of piribedil prolonged-release tablets by adopting the Quality by Design (QbD) approach. The sample preparation involved the direct drop of intact tablets, i.e., tablets crushing was avoided to minimize the assay's inconsistencies.

\section{MATERIAL AND METHODS}

\section{Material:}

The chemicals used in the mobile phase preparation, such as potassium dihydrogen orthophosphate, orthophosphoric acid, and triethylamine (HPLC grade), were obtained from Merck, Mumbai. The hydrochloric acid $(\mathrm{HCl})$ utilized in the diluent preparation was of Analytical grade (AR) and sourced from Rankem, Gurugram. The assay sample solutions were filtered through syringe filters containing Polyvinylidene Flouride (PVDF) membrane of $0.45 \mu \mathrm{m}$ pore size, procured from Merck Millipore. Piribedil (drug substanceand tablets), placeboand the piribedil reference standard were supplied by Dr. Reddy's Laboratories Ltd., Bachupally, Hyderabad. The impurities of piribedil (1-piperonyl piperazine, 2-chloropyrimidine (2-CP or impurity-B), 2-methoxypyrimidine, 2-hydroxypyrimidine and piperonal) were also provided by Dr. Reddy's Laboratories Ltd, Bachupally, Hyderabad. The purity of the piribedil reference standard was $99.5 \%$. The structure of piribedil is given in fig. 1.

\section{Instruments:}

Analytical method development and validation were accomplished using Waters Alliance HPLC with a quaternary pump, auto sampler, photodiode detector and column oven (Waters Corporation, Milford, USA). Empower Networking software (Waters Corporation, Milford, USA) was utilized to acquire and process the chromatographic data. For separating the peaks chromatographically, Hypersil gold C18, $(4.6 \times 150)$ $\mathrm{mm}, 5 \mu \mathrm{m}$ column was used, which was procured from Thermo Fisher Scientific, PA, United States.

\section{Chromatographic conditions:}

The mobile phase consisted of phosphate buffer with $0.01 \%$ triethylamine $(\mathrm{pH} 2.5 ; 50 \mathrm{mM})$, mixed with acetonitrile in the ratio of $80: 20 \mathrm{v} / \mathrm{v}$. The chromatographic separation was achieved in isocratic elution mode by using Hypersil gold C18, $(4.6 \times 150)$

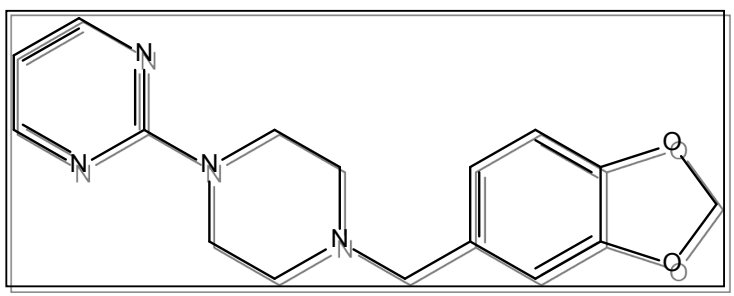

Fig. 1: Structure of piribedil 
$\mathrm{mm}, 5 \mu \mathrm{m}$ column within a runtime of $5 \mathrm{~min}$. The mobile phase was pumped at a flow rate of $1.3 \mathrm{ml} / \mathrm{min}$ and the column was maintained at $30^{\circ}$. The injection volume was fixed as $5 \mu \mathrm{l}$ and the peak areas were determined at $238 \mathrm{~nm}$.

\section{Solution Preparations:}

Diluent: For the preparation of standard and sample solutions, three diluents were used. The $\mathrm{HCl}$ $(0.1 \mathrm{~N})$ was used as a diluent- 1 , whereas a premix of $0.1 \mathrm{~N} \mathrm{HCl}$ and acetonitrile in the ratio of $60: 40 \mathrm{v} / \mathrm{v}$ was used as diluent-2. The phosphate buffer with $0.01 \%$ triethylamine $(\mathrm{pH} 2.5 ; 50 \mathrm{mM})$ and acetonitrile were mixed in the ratio of 80:20 v/v to prepare diluent-3.

Standard solution: Assay of piribedil tablet was estimated against a standard solution of known concentration. The standard stock solution was prepared by accurately weighing and dissolving an appropriate quantity of piribedil reference standard in the diluent-1 to obtain $1000 \mu \mathrm{g} / \mathrm{ml}$ concentration of piribedil. The stock solution was consecutively diluted with diluent-2 for making a standard solution with $50 \mu \mathrm{g} / \mathrm{ml}$ concentration.

Preparation of test solution: Piribedil prolongedrelease tablets (10 Nos.) were transferred to a $500 \mathrm{ml}$ volumetric flask containing $100 \mathrm{ml}$ of diluent-1. The flask was kept for sonication for $40 \mathrm{~min}$ in an ultrasonic bath to disintegrate the tablets completely. After the tablets' complete disintegration, $250 \mathrm{ml}$ of diluent-2 was added and the solution was shaken on a rotary shaker for $15 \mathrm{~min}$. Finally, the solution was sonicated for additional $15 \mathrm{~min}$ and the volume was made up to $500 \mathrm{ml}$ with diluent-2. The sample stock solution was centrifuged for $10 \mathrm{~min}$ at $4000 \mathrm{rpm}$ and $5 \mathrm{ml}$ of clear supernatant was diluted to $100 \mathrm{ml}$ with diluent-3.

\section{Method development by using QbD approach:}

The analytical method was developed by adopting the $\mathrm{QbD}$ approach, which is based on designing the analytical method on deep scientific understanding.
The risk assessment helps identify the critical method parameters, which are further optimized by performing the Design of experiments (DoE). Based on the DoE, the Method Operable Design Range (MODR) is established and the control strategy is defined ${ }^{[17]}$. The QbD approach was implemented for both chromatographic condition development and sample preparation optimization.

\section{HPLC method development:}

Critical Quality Attributes (CQA) and Quality Target Method Profile (QTMP): For assay estimation, HPLC was chosen as a separation and quantification technique. Therefore, based on separation technique and the method intent, CQAs were defined. QTMP is the selected CQA's target profile and was defined based on the planned usage of the method and regulatory requirements (Table 1).

Initial risk assessment: The risk was assessed based on the reported information and prior knowledge. The separation between known/unknown degradation products and piribedil was identified as one of the risks. In addition to this, the robustness of sample preparation was also considered critical to producing consistent assay value.

Development and optimization of chromatographic conditions: Piribedil is soluble in methanol; hence, a piribedil $(100 \mu \mathrm{g} / \mathrm{ml})$ solution was prepared in methanol and injected into HPLC with a Photo Diode Array (PDA) detector to record the ultraviolet spectrum. It was observed that piribedil has two absorption maxima, i.e., $210 \mathrm{~nm}$ and $238 \mathrm{~nm}$. Basis the method sensitivity requirements, $238 \mathrm{~nm}$ was selected as the detection wavelength. Piribedil has pKa values of 6.91 and 1.3. As the objective was to develop an analytical method with a shorter runtime, the buffer $\mathrm{pH}$ was selected in the acidic $\mathrm{pH}$ range $(\mathrm{pH} 2.5)$ to have the optimum retention. Phosphate buffer (Potassium Dihydrogen Phosphate $\left(\mathrm{KH}_{2} \mathrm{PO}_{4}\right) 50 \mathrm{mM}$ ) was selected as the aqueous portion of the mobile phase and acetonitrile was selected as the organic modifier. Triethylamine was also added to the

TABLE 1: CRITICAL QUALITY ATTRIBUTES AND QUALITY TARGET METHOD PROFILE

\begin{tabular}{|c|c|c|}
\hline S. No. & CQA & QTMP \\
\hline 1 & Symmetry factor for piribedil peak & NMT 1.5 \\
\hline 2 & $\%$ RSD of piribedil peak area from replicate injections of standard & NMT 2.0 \\
\hline 3 & Plate counts for piribedil peak & NLT 4000 \\
\hline 4 & Interference due to known impurities & No \\
\hline 5 & Interference due to degradation-products generated during forced degradation & No \\
\hline 6 & Recovery of the drug from the sample matrix & $97.0 \%$ to $103.0 \%$ \\
\hline 7 & Run time & NMT 5 min \\
\hline
\end{tabular}

Note: CQA: Critical Quality Attributes; QTMP: Quality Target Method Profile; \% RSD: Percentage Relative Standard Deviation; NMT: Not More Than and NLT: Not Less Than 
mobile phase to improve the peak shape, and the final mobile phase buffer consisted of $50 \mathrm{mM} \mathrm{KH}_{2} \mathrm{PO}_{4} \mathrm{pH}$ 2.5 with $0.01 \%$ triethylamine.

The $\mathrm{C}_{18}$ columns of various manufacturers were explored to have a better peak shape with a shorter runtime. Xterra $\mathrm{RP}_{18}(4.6 \times 150) \mathrm{mm}, 5 \mu \mathrm{m}$ (column-1), Inertsil ODS $3 \mathrm{~V},(4.6 \times 150) \mathrm{mm}, 5 \mu \mathrm{m}$ (column-2) and Hypersil gold $\mathrm{C}_{18},(4.6 \times 150) \mathrm{mm}, 5 \mu \mathrm{m}$ (column-3) were used as part of column screening. Hypersil gold column was found as the most suitable column. The column flow was optimized as $1.3 \mathrm{ml} / \mathrm{min}$ and the injection volume was chosen as $5 \mu 1$. The column oven was attained at $30^{\circ}$.

In assay method, separation of piribedil from known impurities and degradation products (generated during forced degradation) is one of the QTMP. To verify this, known impurities such as 1-piperonyl piperazine, 2-CP or impurity-B, 2-methoxypyrimidine, 2-hydroxypyrimidine and piperonal were injected into the finalized method at $1.0 \%$ concentration level. Additionally, the piribedil sample was stressed under various degradation conditions (e.g., acid hydrolysis, base hydrolysis, oxidative stress and heat stress) and the stressed samples were injected into HPLC by following the method conditions. 2-CP or impurity-B peak was found eluting closely with the piribedil peak. In oxidative stress also, one unknown impurity was eluting after the piribedil peak (fig. 2).

Identification of Critical Method Parameters (CMP): Based on the understanding developed during method development, the resolution between 2-CP or impurity-B and piribedil peak and between piribedil peak and unknown impurity in the oxidatively stressed sample (peroxide impurity) were found to be critical. The $\mathrm{pH}$ of the buffer, $\%$ acetonitrile in the mobile phase and the column oven temperature are the potential CMP that can impact these critical separations. Hence these parameters were selected as CMP for further optimization by conducting the DoE.

DoE: The $\mathrm{pH}$ of buffer, Percentage (\%) acetonitrile in the MP and column oven temperature were recognized as critical method parameters that were further studied by doing the design of the experiment. A full factorial design with three center points was selected and the design was created by employing Design Expert (Version 10.0.3, Stat-Ease Inc.). Piribedil tablet solution, stressed under oxidative stress condition, was spiked with 2-CP or impurity-B at $1.0 \%$ level and this sample was used for the DoE study. Details of the factors and responses selected are given in Table 2 and Table 3, respectively.

\section{Sample preparation optimization:}

Piribedil is a prolonged-release tablet consisting of various release controlling polymers. Basis the solubility study, piribedil was found to have maximum solubility in $0.1 \mathrm{~N} \mathrm{HCl}$; hence it was chosen as the aqueous portion of diluent. The mobile phase contains acetonitrile as an organic modifier; hence acetonitrile was selected as the organic solvent for diluent preparation. For sample preparation, the intact tablet direct dropping method was selected to overcome the tablet crushing method's limitations.

Various extraction techniques (shaking on the mechanical shaker, sonication) were explored for drug extraction, but none of the techniques served the

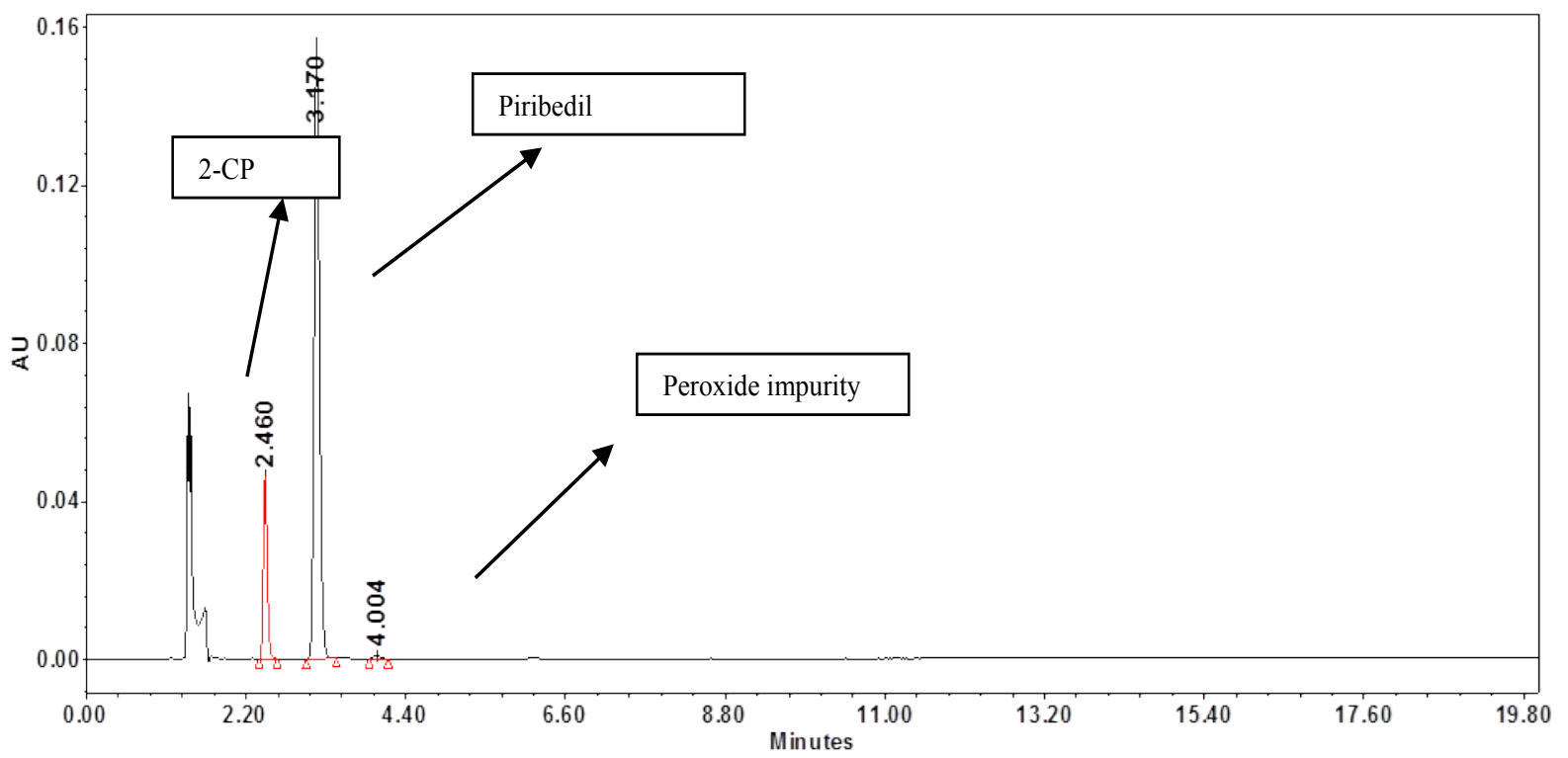

Fig. 2: Chromatogram of oxidatively stressed piribedil tablet spiked with 2-cp impurity 
purpose when used independently. Thus, to have the optimum extraction efficiency, the sonicator and shaker were used in combination. Ten tablets were used for sample preparation to make the sample composite and representative. The tablets were dispersed by adding $0.1 \mathrm{~N} \mathrm{HCl}$ (diluent-1) and the solution was kept on a mechanical shaker for the disintegration of tablets. After $60 \mathrm{~min}$ also, tablets were not disintegrated completely. The ultrasonic bath (sonicator) creates much stronger ultrasonic waves; hence the shaker was replaced with a sonicator to disintegrate the tablets. By using the sonicator, tablets got disintegrated entirely within 30-40 min. To further extract the drug from dispersed tablets, the sample solution was shaken on a mechanical shaker for 10-15 min. Finally, to ensure the complete drug extraction, the solution was again sonicated for 10-15 min and the volume was made up to $500 \mathrm{ml}$ with diluent. The finalized sample preparation is summarized in fig. 3 .

The robustness of sample preparation is an essential aspect in assay analysis for getting accurate data. As the sample preparation involves multiple steps, each step can add some analysis variations if not executed properly. Hence to understand the critical steps in sample preparation and define the design space for each step, the DoE study was performed.

DoE: The volume of diluent-1 $(0.1 \mathrm{~N} \mathrm{HCl})$ added in step-2, shaking time in step-3 and sonication time in step-4 were selected as critical method parameters, which were further optimized by conducting the DoE. Assay of piribedil was chosen as a response. A full factorial design with two center points (total ten runs) was selected and the design was created by using Design Expert Software (Version 10.0.3, Stat-Ease Inc.).The details of the input factors are given in Table 4.

\section{Method validation:}

After the development of the analytical method, method suitability was verified by performing the method validation. The method validation was performed as per International Council on Harmonisation (ICH) guideline ${ }^{[18]}$.

System suitability: The system suitability was ensured by injecting five replicate injections of the piribedil standard solution $(50 \mu \mathrm{g} / \mathrm{ml})$. The Percentage Relative

\section{TABLE 2: INPUT FACTORS CHOSEN FOR CHROMATOGRAPHIC CONDITION DOE}

\begin{tabular}{lcccccc}
\hline Factor & Name & Units & Type & Minimum & Center Point & Maximum \\
\hline A & pH of Buffer & - & Numeric & 2.3 & 2.5 & 2.7 \\
B & \% Acetonitrile mobile phase & $\%$ & Numeric & 90 & 100 & 110 \\
C & Column oven temperature & $\circ$ & Numeric & 25 & 30 & 35 \\
\hline
\end{tabular}

Note: DoE: Design of Experiments

\section{TABLE 3: RESPONSES CHOSEN FOR CHROMATOGRAPHIC CONDITION DOE}

\begin{tabular}{lccc}
\hline Response & Name & Target & Model \\
\hline R1 & Resolution between 2-CP (imp B) and piribedil peak & 2 & Reduced main effects \\
R2 & Resolution between piribedil and unknown impurity peak (peroxide imp) & 2 & Reduced main effects \\
\hline
\end{tabular}

Note: DoE: Design of Experiments; 2-CP: 2-chloropyrimidine and Imp-B: Impurity-B

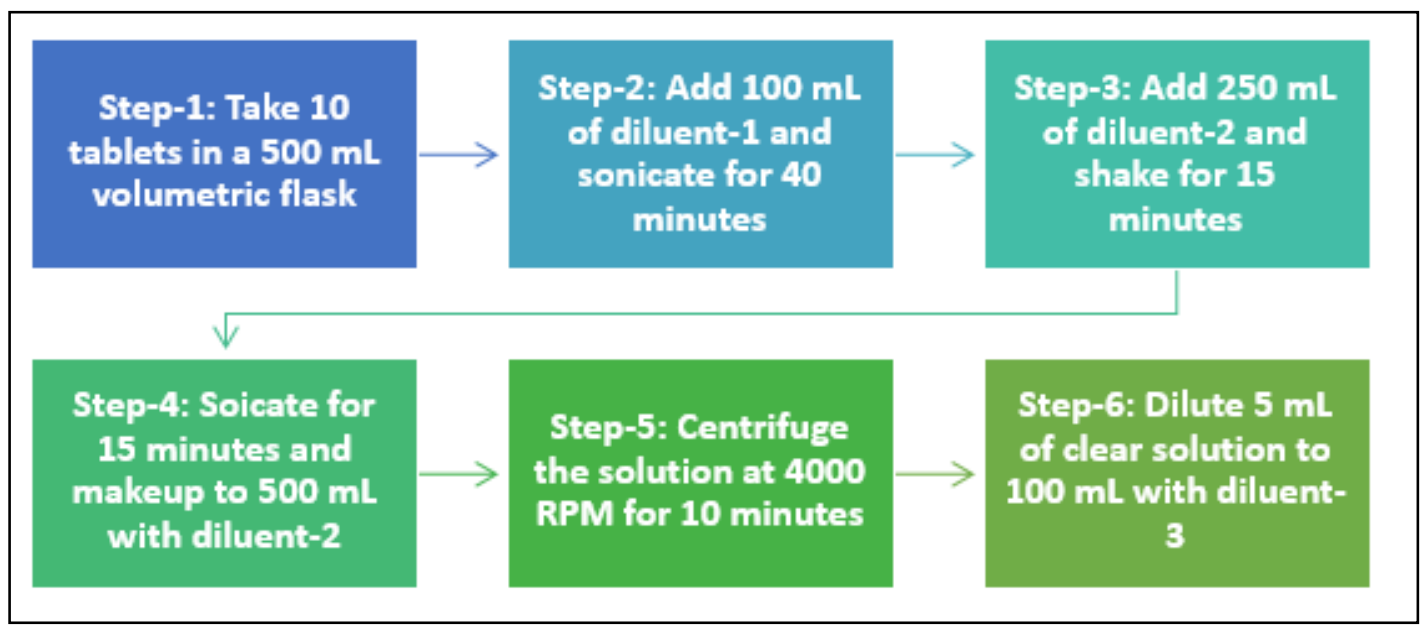

Fig. 3: Assay sample preparation steps 
Standard Deviation (\% RSD) of peak area of piribedil from five replicate injections of the standard was determined. Piribedil peak was also evaluated for peak tailing and plate counts.

Specificity: The specificity study comprised of placebo interference, impurity interference and forced degradation studies. The placebo interference was demonstrated to rule out any interference at the piribedil's retention time due to the excipients used in tablet formulation. The stability-indicating nature of the analytical method was established by doing forced degradation studies. Additionally, impurity interference was also performed to ensure that the known impurities do not interfere in piribedil quantification.

As part of the placebo interference study, two placebo samples were prepared using placebo equivalent to test preparation. The placebo preparations were injected into HPLC and chromatograms were assessed for any interference at piribedil's retention time. The impurity profile of piribedil prolonged-release tablets consists of five known impurities such as 1-piperonyl piperazine, 2-CP or impurity-B, 2-methoxypyrimidine, 2-hydroxypyrimidine, and piperonal. The individual solutions were prepared to achieve a $0.5 \mu \mathrm{g} / \mathrm{ml}$ concentration of each known impurity. HPLC analyzed these impurity solutions and the chromatograms of impurities were overlaid with piribedil standard solution.

Piribedil prolonged-release tablets were exposed to various stress conditions in solid (heat stress, humidity stress and photolytic stress) and liquid form (acid hydrolysis, base hydrolysis, neutral hydrolysis and oxidative stress). The stressed samples were injected into HPLC with a PDA detector and were evaluated for piribedil's peak purity. The details of each stress condition are given in Table 5.

Linearity: The linearity study was performed from $20 \%$ to $150 \%$ of the target concentration $(50 \mu \mathrm{g} / \mathrm{ml})$. Six linearity solutions were prepared from $10 \mu \mathrm{g} / \mathrm{ml}$ to $75 \mu \mathrm{g} / \mathrm{ml}$ and injected into the HPLC. The peak area of piribedil was recorded in each linearity solution and plotted against the concentration. The correlation coefficient, intercept, slope and \% bias at $100 \%$ response were estimated.

Method precision: The precision study consisted of method precision and intermediate precision. As part of method precision, six samples were prepared using piribedil prolonged-release tablets from a pool of tablets. The samples were analyzed as per method parameters and \% assay of piribedil and \% RSD of assay values from six samples were calculated. During intermediate precision, six samples were prepared by two different analysts on two different days and were analyzed on two different HPLC with two different columns. The $\%$ assay and $\%$ RSD of assay value from six samples were calculated.

Accuracy: The accuracy study was performed at four levels, i.e., $20 \%$ to $150 \%$ of target initial concentration $(1000 \mu \mathrm{g} / \mathrm{ml})$. During the accuracy study, the number of tablets was changed according to accuracy levels,

TABLE 4: INPUT FACTORS CHOSEN FOR SAMPLE PREPARATION DOE

\begin{tabular}{lcccccc}
\hline Factor & Name & Units & Type & Minimum & Center Point & Maximum \\
\hline A & Volume of diluent-1 added in step-2 & $\mathrm{ml}$ & Numeric & 80 & 100 & 120 \\
B & Shaking time in step-3 & min & Numeric & 10 & 15 & 20 \\
C & Sonication time in step-4 & min & Numeric & 10 & 15 & 20 \\
\hline
\end{tabular}

Note: DoE: Design of Experiments

TABLE 5: SUMMARY OF FORCED DEGRADATION STUDIES

\begin{tabular}{|c|c|c|c|c|c|}
\hline Type of stress & Stress condition & \% Assay & Purity angle & $\begin{array}{l}\text { Purity } \\
\text { threshold }\end{array}$ & Purity flag \\
\hline Control sample & Not applicable & 98.8 & 0.152 & 0.360 & No \\
\hline Acid hydrolysis & $5 \mathrm{ml}$ of $2 \mathrm{~N} \mathrm{HCl}, 70^{\circ}, 24 \mathrm{~h}$ & 97.9 & 0.159 & 0.356 & No \\
\hline Base hydrolysis & $5 \mathrm{ml}$ of $2 \mathrm{~N} \mathrm{NaOH} 70^{\circ}, 24 \mathrm{~h}$ & 97.3 & 0.197 & 0.372 & No \\
\hline Neutral hydrolysis & $5 \mathrm{ml}$ of water, $70^{\circ}, 24 \mathrm{~h}$ & 100.1 & 0.139 & 0.417 & No \\
\hline Oxidative stress & $6 \% \mathrm{H}_{2} \mathrm{O}_{2}$ at $25^{\circ}, 3 \mathrm{~h}$ & 95.9 & 0.147 & 0.386 & No \\
\hline Heat stress & $70^{\circ}$ for $24 \mathrm{~h}$ & 98.3 & 0.148 & 0.349 & No \\
\hline Humidity stress & $90 \% \mathrm{RH}, 25^{\circ}, 9 \mathrm{~d}$ & 98.5 & 0.141 & 0.352 & No \\
\hline Photolytic stress & $\begin{array}{c}1.2 \text { million lux } \mathrm{h} \text { visible light and } 200 \\
\mathrm{wh} / \mathrm{m}^{2} \mathrm{UV} \text { light }\end{array}$ & 98.7 & 0.156 & 0.391 & No \\
\hline
\end{tabular}

Note: $\mathrm{HCl}$ : Hydrochloric Acid; $\mathrm{NaOH}$ : Sodium Hydroxide; $\mathrm{H}_{2} \mathrm{O}_{2}$ : Hydrogen peroxide and RH: Relative Humidity 
i.e., for $20 \%$ accuracy level, two tablets were taken; similarly, for $150 \%$ level, 15 tablets were taken for sample preparation. The samples were injected into HPLC by following the method defined conditions and $\%$ recovery values were calculated for all the samples.

Filter validation: To choose a suitable filter for filtering the sample solution, a filter validation study was performed. The sample solutions were prepared in duplicate by using piribedil prolonged-release tablets and were filtered through two different types of filters (0.45 $\mu \mathrm{m}$ PVDF and $0.45 \mu \mathrm{m}$ nylon). The piribedil assay in filtered samples was evaluated against the assay of the centrifuged sample.

Stability of test solution and mobile phase: A stability study for standard and sample solution was carried out to define the storage condition and storage duration. The stability study was carried out at controlled room temperature $\left(25^{\circ} \pm 2^{\circ}\right)$ and in a refrigerator $\left(5^{\circ} \pm 3^{\circ}\right)$ by storing the standard and sample solutions. The similarity factor was calculated for the standard solution, whereas for sample solution, $\%$ difference in assay from initial value was calculated.

\section{RESULTS AND DISCUSSION}

The critical method parameters were studied by performing DoE. The runs produced by the Design Expert were executed and data was collected for the selected responses. The datasets were examined using the Analysis of Variance (ANOVA) model. The main observations based on data analysis are summarized (fig. 4 and fig. 5).

The $\mathrm{pH}$ of buffer and column oven temperature did not impact the selected responses (R1 and R2) significantly; the concentration of Acetonitrile (organic phase) in mobile phase had an impact on the responses (R1 and $\mathrm{R} 2$ ); as the acetonitrile concentration in the mobile phase increased, the resolution (R1 and R2) decreased. However, the resolution (R1 and R2) remained within the defined QTMP.

The resolution between 2-CP (Impurity-B) and piribedil peak and piribedil peak and unknown impurity in oxidative stress (peroxide impurity) were found to be more than 2 across the entire range of input factors (fig. 5). Therefore, it can be inferred that the method is robust in the entire range covered during DoE. The established MODR is: Column oven temperature from $25^{\circ}$ to $35^{\circ}\left( \pm 5^{\circ}\right.$ from the method defined temperature); acetonitrile concentration $90 \%$ to $110 \%( \pm 10 \%)$; pH

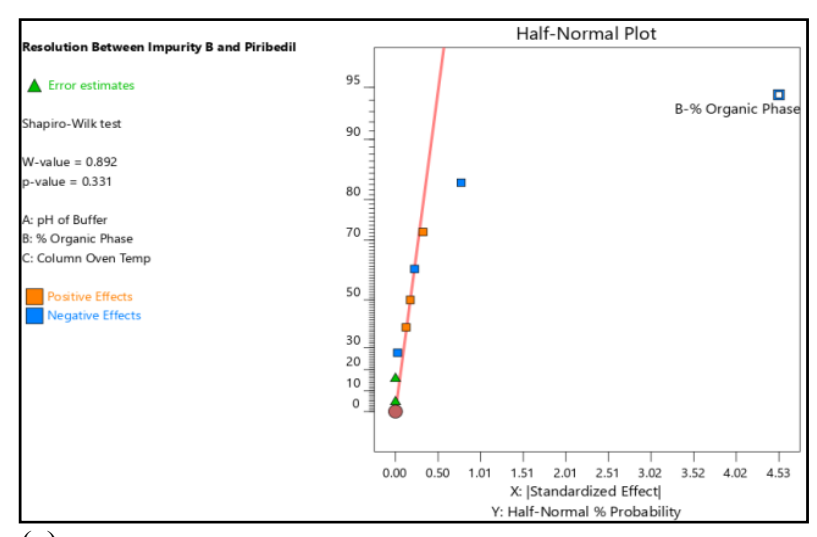

(a)

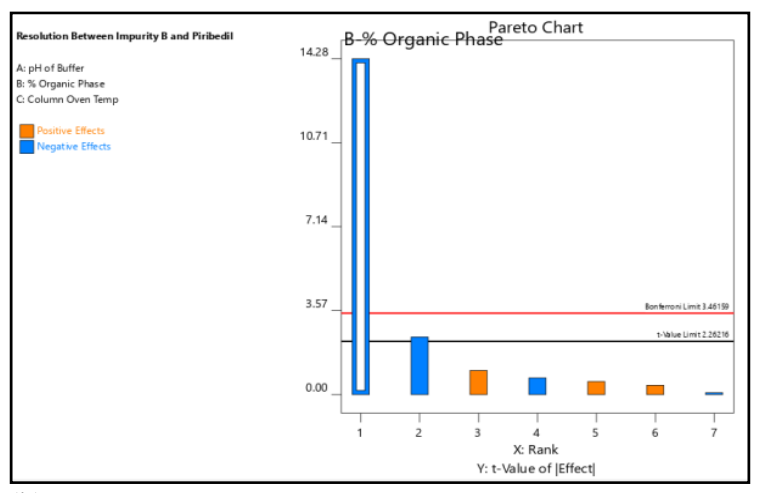

(b)

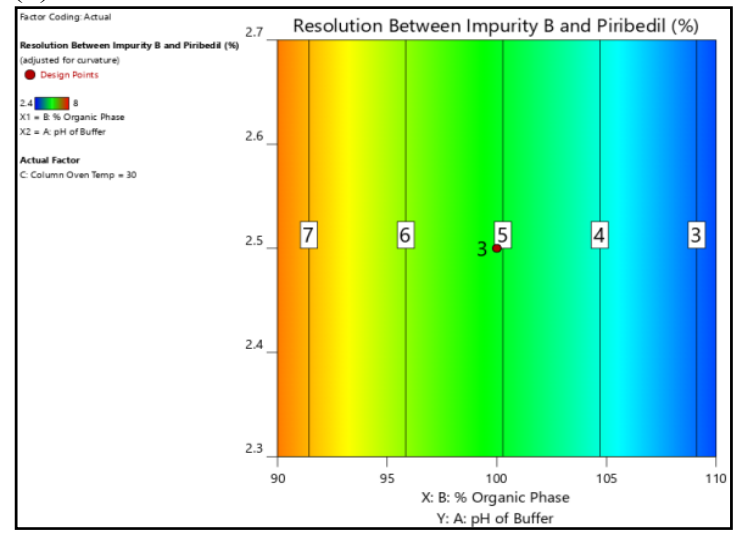

(c)

Fig. 4: Data analysis for R1 (a) Half nominal plot; (b) Pareto chart and (c) Contour plot

of the mobile phase from 2.3 to 2.7 ( \pm 0.2 from the method defined $\mathrm{pH}$ ).

Basis the DoE study, MODR was established and the method was found robust within the studied ranges. The concentration of acetonitrile played a vital role in the separation, hence while preparing the mobile phase, an accurate volume of acetonitrile should be added. Therefore a precautionary note was added in the method of analysis relate to the same.

The critical sample preparation steps were optimized with the help of DoE. The experiments suggested by the Design Expert were performed and data were 


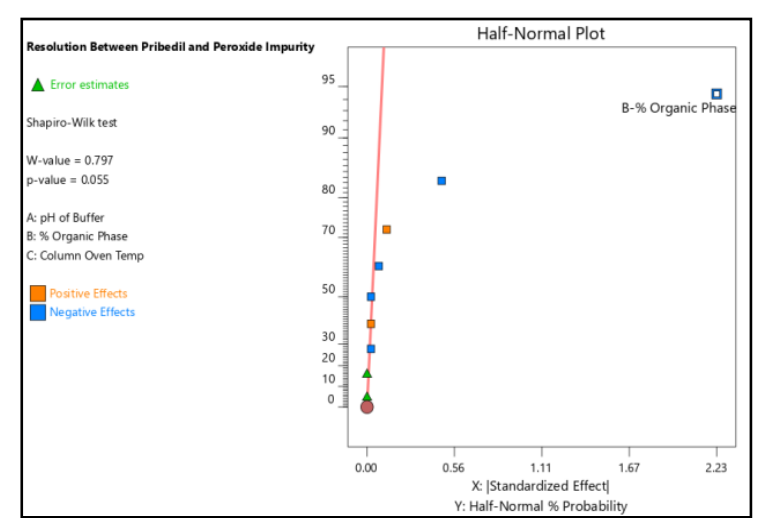

(a)

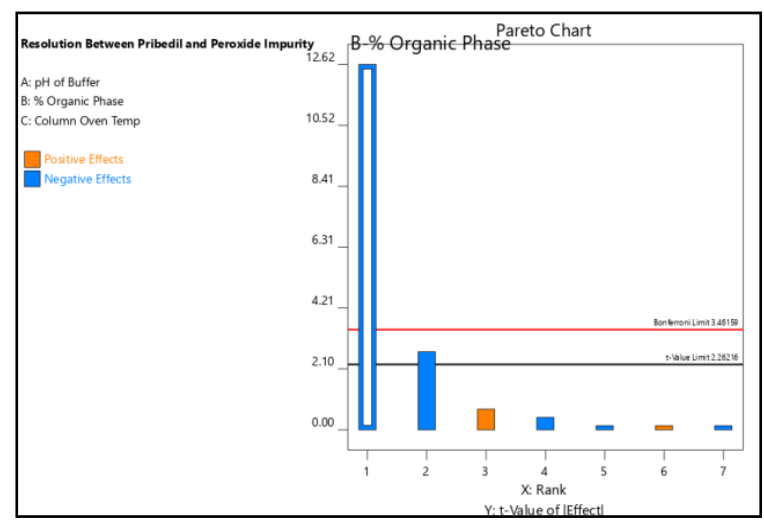

(b)

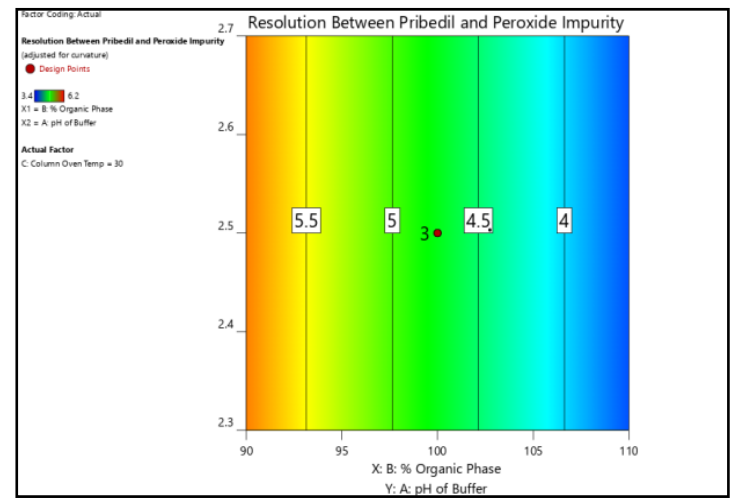

(c)

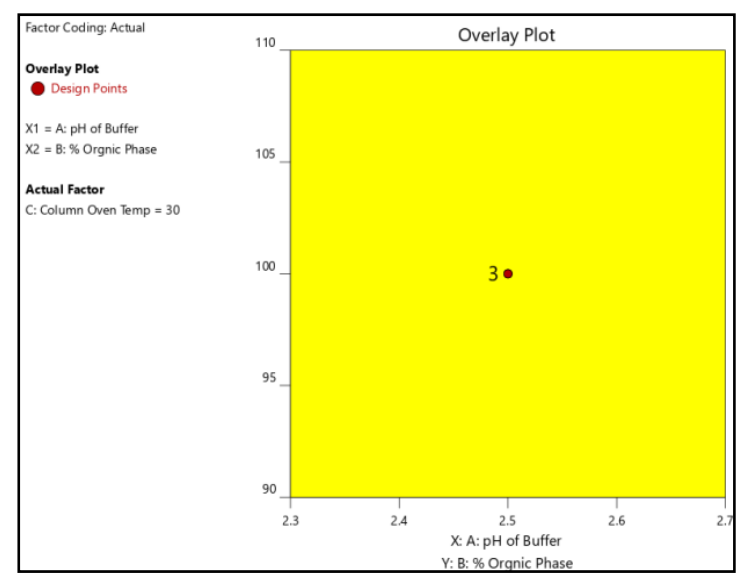

(d)

Fig. 5: Data analysis for R2 (a) Half nominal plot; (b) Pareto chart; (c) Contour plot and (d) Overlaid plot acquired for the chosen responses. The data sets were further studied using the ANOVA model. The key interpretations based on data analysis are summarized (fig. 6). The volume of diluent-1 or $0.1 \mathrm{~N} \mathrm{HCl}$ and sonication time did not have any impact on the selected response. The shaking time had an impact on the selected response; however, no significant change in the assay was observed across the entire range of the input factors.

Assay values did not change significantly in all the altered conditions; hence, the sample preparation
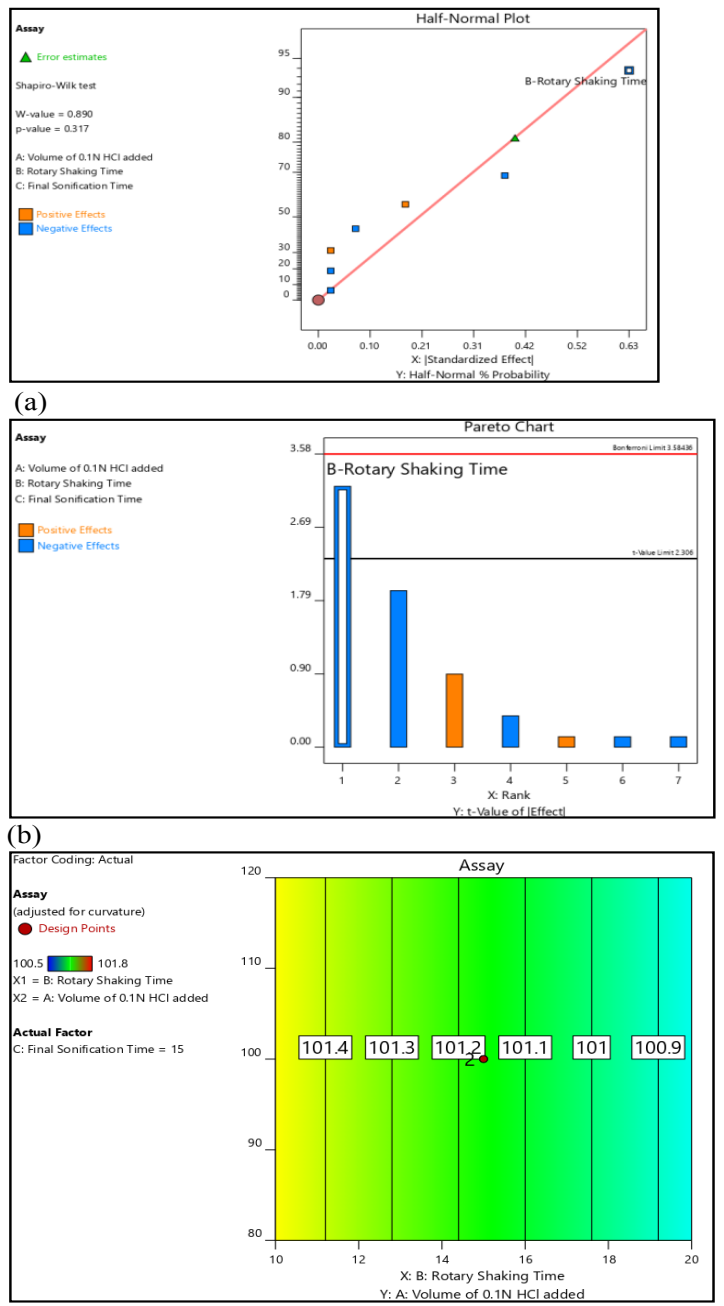

(c)

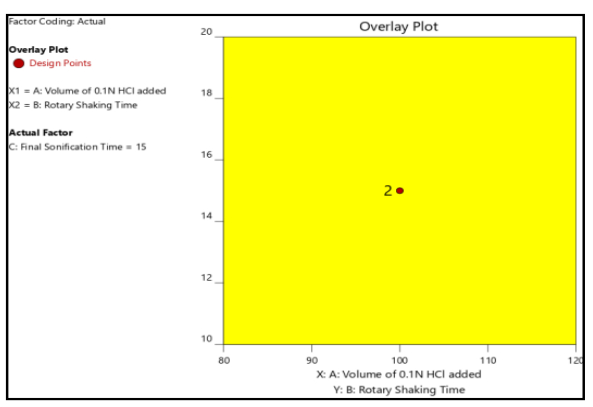

(d)

Fig. 6: Data analysis of sample preparation DoE (a) Half nominal plot; (b) Pareto chart; (c) Contour plot and (d) Overlaid plot 
procedure was robust over the entire study range. MODR was defined as $\pm 20 \mathrm{ml}$ for diluent- $1(0.1 \mathrm{~N} \mathrm{HCl})$ volume addition, whereas it was \pm 5 min for shaking time and sonication time (fig. 6).

The method was validated as per ICH Guideline for validation of analytical procedures for specificity, precision, linearity, recovery, robustness and ruggedness.

The \% RSD was observed as 0.4 against a limit of Not More Than (NMT) 2.0, whereas USP peak tailing and plate counts were observed as 1.2 and 8500 , respectively. All the system suitability parameters were meeting the predefined acceptance criteria. The specimen chromatograms of blank (diluent) and standard preparation are given in fig. 7.

Specificity was demonstrated by doing placebo interference, impurity interference and forced degradation studies. The placebo preparations did not show any peak at the retention times of piribedil. In impurity interference, no impurity was found eluting at piribedil's retention time (fig. 8). In oxidative stress conditions, moderate degradation was observed and

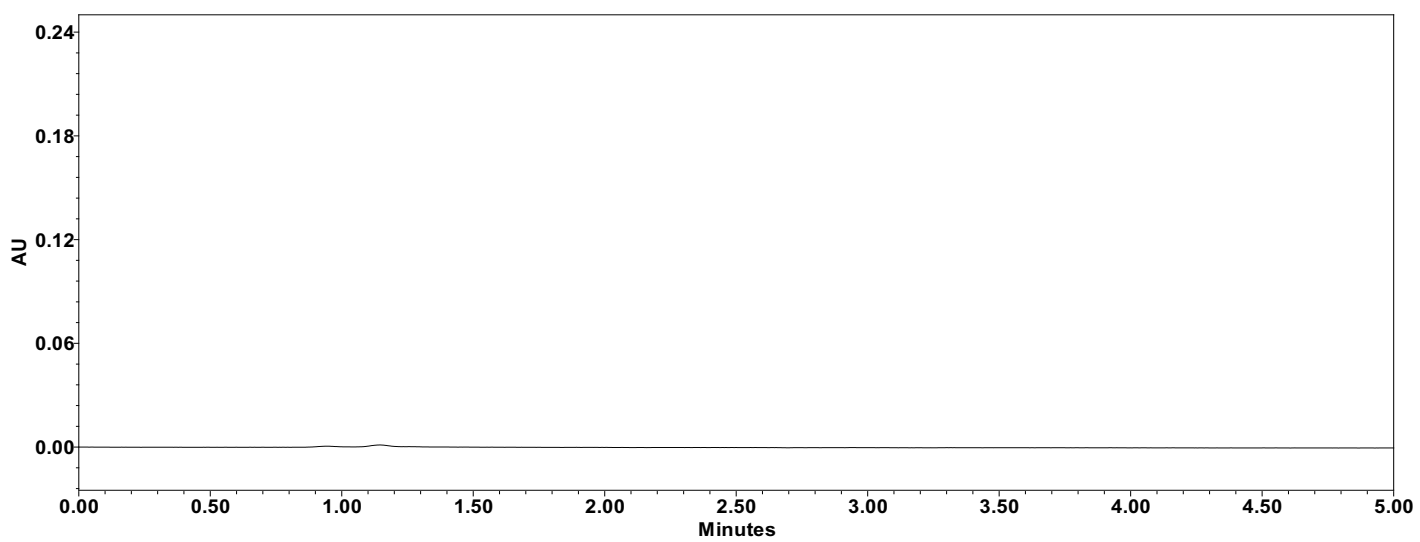

(a)

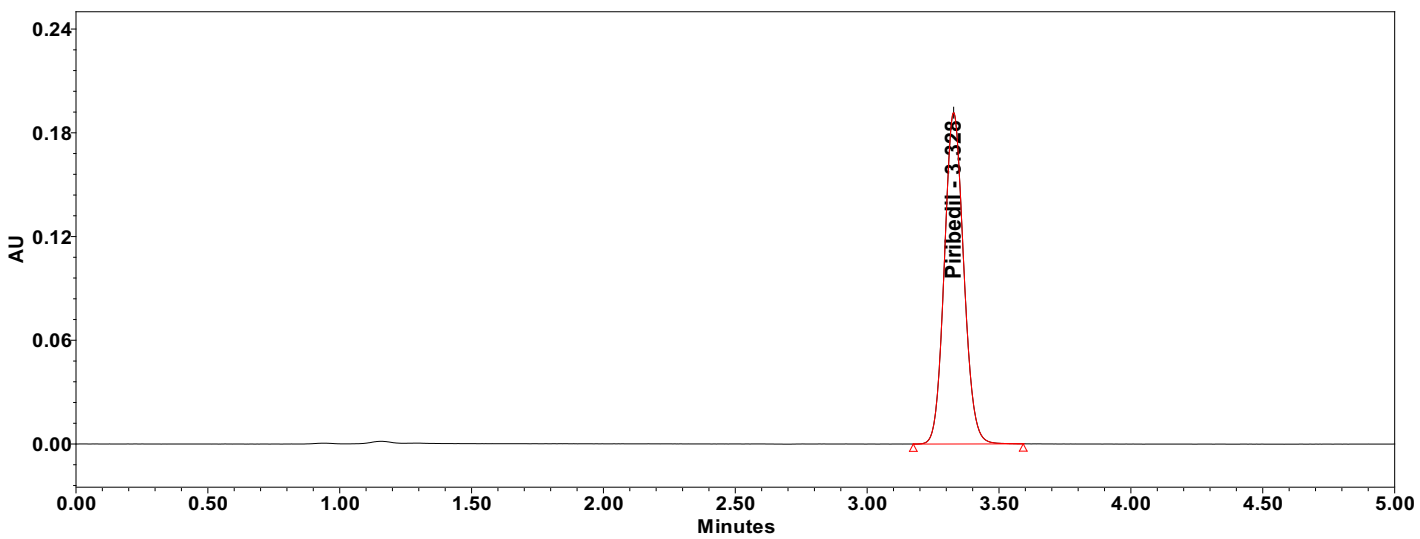

(b)

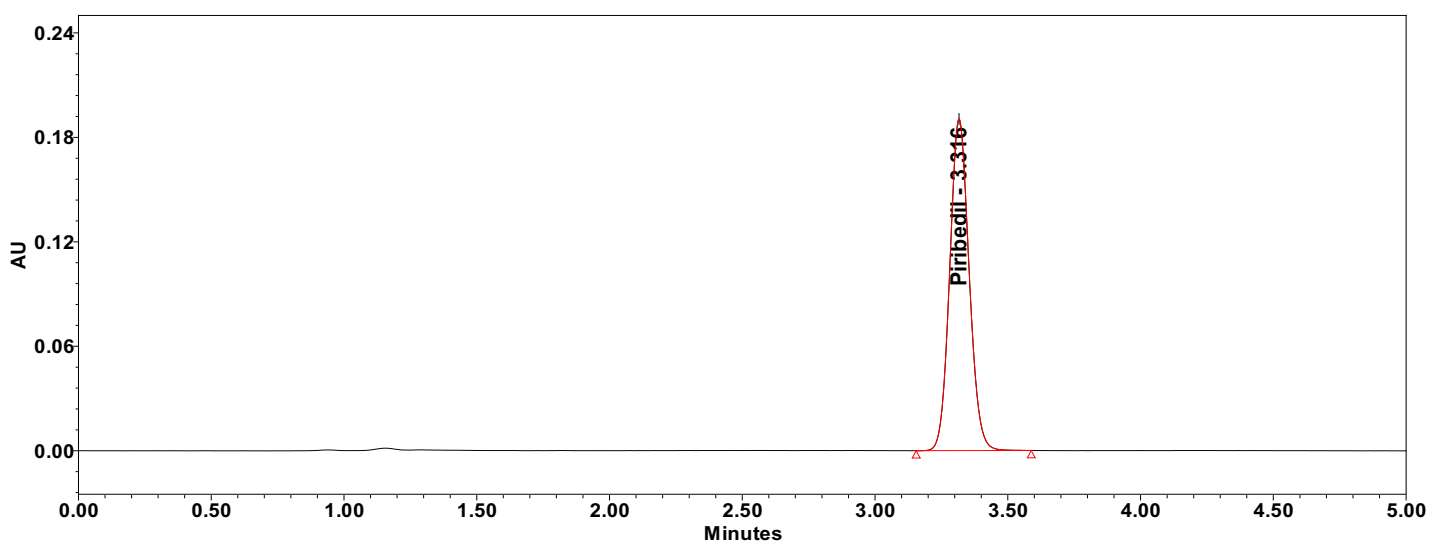

(c)

Fig. 7: Chromatograms of piribedil (a) Blank; (b) Standard and (c) Test solution 
an unknown impurity at 1.25 Relative Retention Time (RRT) was observed. In acid and base hydrolysis conditions, unknown impurities at 0.55 and 0.49 RRT were observed; however, no degradation was observed in other stressed conditions. Hence it can be concluded that piribedil is stable under these conditions. The peak purity of piribedil was found passing in all the stress conditions (Table 5); hence the analytical method can separate the degradation products from piribedil peak (fig. 9).

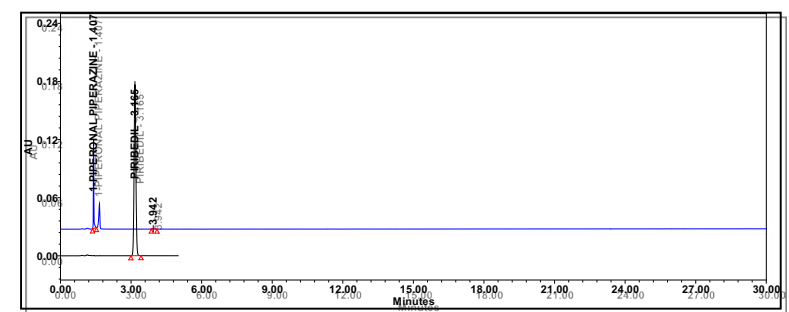

(a)

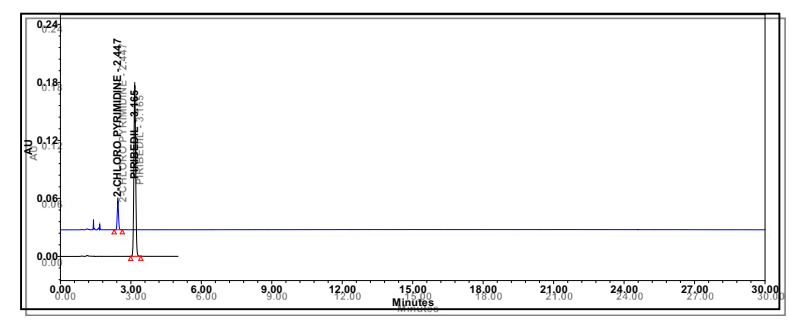

(b)

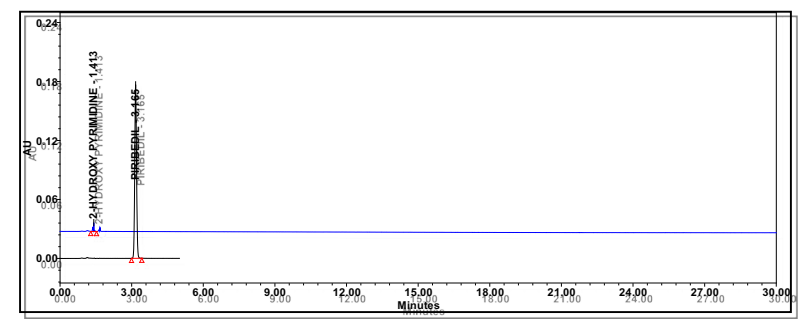

(c)

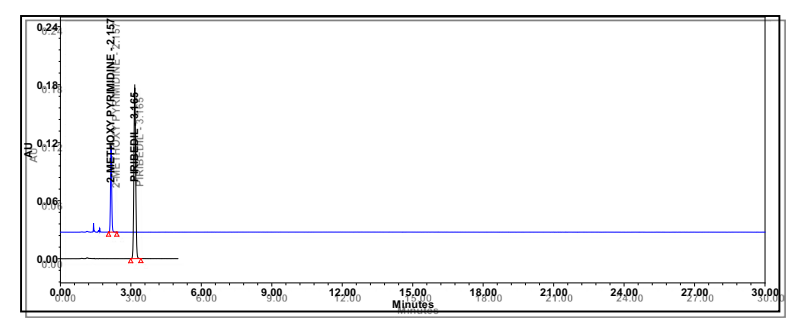

(d)

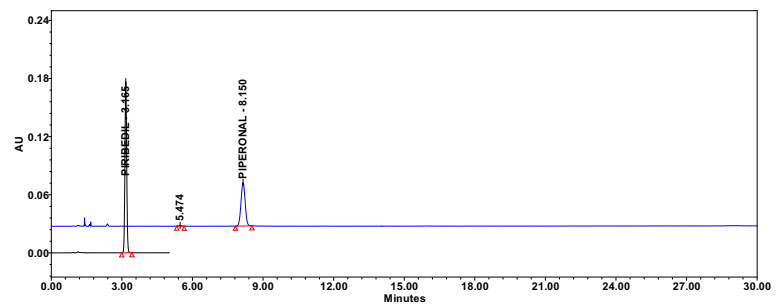

(e)

Fig. 8: Overlaid chromatograms of piribedil with impurities (a) piribedil and 1-PP; (b) piribedil and 2-CP; (c) piribedil and 2-HP; (d) piribedil and 2-MP and (e) piribedil and piperonal
The linearity study demonstrated that detector response is linear for piribedil across the method range. The correlation coefficient, intercept, slope and $\%$ bias at $100 \%$ response were estimated. The linearity results are given in Table 6 .

Precision and intermediate precision studies were performed to show that the method is precise for estimating piribedil in piribedil prolonged tablets. In the precision study, the individual assay values were observed between $98.2 \%$ to $101.0 \%$, with a $\%$ RSD of 0.9. A specimen chromatogram of piribedil prolonged release tablet sample solution is given as fig. 7. During intermediate precision, the $\%$ assay and $\%$ RSD of assay value from six samples were calculated. The individual assay values ranged from 98.0 to 101.5 , with a $\%$ RSD of 0.9. The results are specified in Table 7 .

The accuracy study was performed at four levels ranging from $20 \%$ to $150 \%$ of target initial concentration $(1000 \mu \mathrm{g} / \mathrm{ml})$ and the values were found between $98.8 \%$ and $100.5 \%$ against a specification of $97.0 \%$ to $103.0 \%$. The results are specified in Table 8 .

In filter validation study, the filtered samples' assay values, using $0.45 \mu \mathrm{m}$ PVDF and $0.45 \mu \mathrm{m}$ nylon filters, did not vary more than $2 \%$ compared against the centrifuged sample. Therefore, both the filters

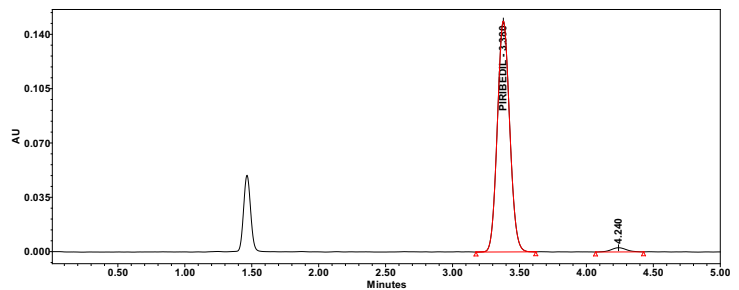

(a)

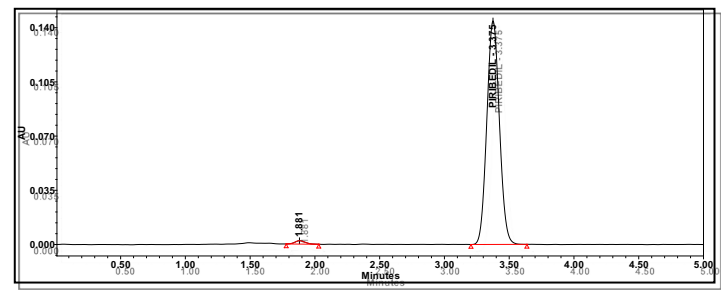

(b)

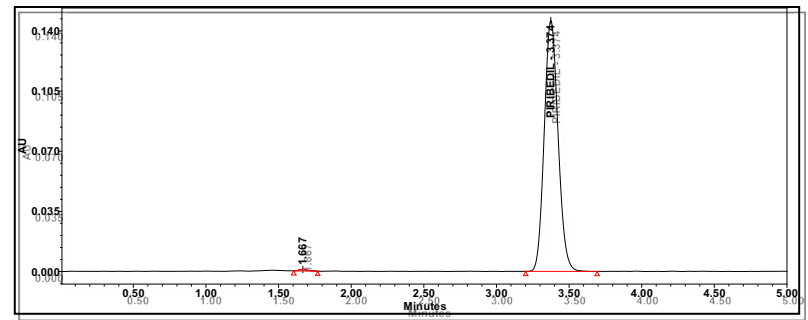

(c)

Fig. 9: Chromatograms of piribedil stressed under various conditions (a) Oxidative stressed; (b) Acid hydrolysis and (c) Base hydrolysis 
(0.45 $\mu \mathrm{m}$ PVDF and $0.45 \mu \mathrm{m}$ nylon) were found suitable The stored samples' assay values under Controlled for sample solution filtration. The results are given in Table 9.

Room Temperature (CRT) were within $\pm 2.0 \%$ from the initial value, whereas the similarity factor for the stored

The stability study of solutions and mobile phase helped in establishing the storage condition and storage period. standard under CRT was observed between 0.98 and 1.02. Thus, it can be inferred that the standard and test

TABLE 6: RESULTS OF LINEARITY STUDY

\begin{tabular}{|c|c|c|c|}
\hline S. No. & Solution name & Concentration (in $\mu \mathrm{g} / \mathrm{ml}$ ) & Peak area \\
\hline 1 & Linearity solution-1 & 10.0795 & 212203 \\
\hline 2 & Linearity solution-2 & 25.1988 & 519297 \\
\hline 3 & Linearity solution-3 & 38.3022 & 782741 \\
\hline 4 & Linearity solution-4 & 50.3976 & 1023656 \\
\hline 5 & Linearity solution-5 & 62.493 & 1263612 \\
\hline 6 & Linearity solution-6 & 76.6044 & 1570429 \\
\hline \multicolumn{4}{|l|}{ Linearity results } \\
\hline Correlation coefficient & & 0.9999 & \\
\hline Intercept & & 5486.355 & \\
\hline Slope & & 20294.63 & \\
\hline$\%$ Bias at $100 \%$ level & & 0.5 & \\
\hline
\end{tabular}

TABLE 7: RESULTS OF PRECISION STUDY

\begin{tabular}{lccc}
\hline \multirow{2}{*}{ S. } & Sample Name & \multicolumn{2}{c}{ \% Assay } \\
\cline { 3 - 4 } 1 & Test preparation-1 & Method precision & Intermediate precision \\
2 & Test preparation-2 & 100.1 & 99.7 \\
3 & Test preparation-3 & 99.1 & 98 \\
4 & Test preparation-4 & 99.5 & 100.1 \\
5 & Test preparation-5 & 101 & 99.7 \\
6 & Test preparation-6 & 98.2 & 101.5 \\
Statistical evaluation & & 99.6 & 100.5 \\
Average & & & \\
Minimum & & 99.6 & 99.9 \\
Maximum & & 98.2 & 98 \\
\% RSD & & 101.1 & 101.5 \\
\hline
\end{tabular}

Note: \% RSD: Percentage Relative Standard Deviation

TABLE 8: RESULTS OF ACCURACY STUDY

\begin{tabular}{|c|c|c|c|c|c|}
\hline Spike level & Sample No. & mg added & $\mathrm{mg}$ found & \% Recovery & Average \\
\hline & Sample-1 & 99.600 & 99.500 & 99.9 & \\
\hline \multirow[t]{3}{*}{$20 \%$} & Sample-2 & 99.600 & 99.202 & 99.6 & 99.9 \\
\hline & Sample-3 & 99.600 & 99.700 & 100.1 & \\
\hline & Sample-1 & 249.000 & 246.759 & 99.1 & \\
\hline \multirow[t]{3}{*}{$50 \%$} & Sample-2 & 249.000 & 246.510 & 99.0 & 99.1 \\
\hline & Sample-3 & 249.000 & 247.008 & 99.2 & \\
\hline & Sample-1 & 498.000 & 500.490 & 100.5 & \\
\hline \multirow[t]{3}{*}{$100 \%$} & Sample-2 & 498.000 & 495.510 & 99.5 & 100.0 \\
\hline & Sample-3 & 498.000 & 497.502 & 99.9 & \\
\hline & Sample-1 & 747.00 & 745.506 & 99.8 & \\
\hline \multirow[t]{2}{*}{$150 \%$} & Sample-2 & 747.000 & 738.036 & 98.8 & 99.4 \\
\hline & Sample-3 & 747.000 & 743.265 & 99.5 & \\
\hline
\end{tabular}


TABLE 9: RESULTS OF FILTER VALIDATION STUDY

\begin{tabular}{lcccccc}
\hline \multicolumn{5}{c}{ \% Assay } \\
\hline Sample No. & As such & $\mathbf{0 . 4 5} \boldsymbol{\mu m}$ PVDF & \% Difference & $\mathbf{0 . 4 5} \boldsymbol{\mu m}$ nylon & \% Difference \\
\hline 1 & 99.6 & 99.8 & 0.2 & 100.3 & 0.7 \\
2 & 98.2 & 98.5 & 0.3 & 97.5 & 0.8 \\
\hline
\end{tabular}

Note: PVDF: Polyvinylidene Flouride

solutions are stable on the benchtop under controlled room temperature for $5 \mathrm{~d}$.

A novel rapid, specific, stability-indicating RPHPLC method was developed to determine piribedil prolonged-release tablets' assay by adopting the $\mathrm{QbD}$ approach. The proposed analytical method can separate the known impurities and the degradation products from piribedil peak. The MODR was determined for the critical method parameters, and the control strategy was defined. The robustness of sample preparation was demonstrated by conducting DoE. The MODR was defined for sample preparation's critical steps. The proposed method was validated as per ICH guideline Q2 (R1); Guidelines for validation of analytical procedures. It is a simple HPLC method, which can be used as a quality control tool for batch release.

\section{Acknowledgements:}

The author would take this opportunity to acknowledge the support provided by Dr. Reddy's Laboratories' management during this research work by providing the necessary materials and facility.

\section{Conflict of interests:}

The authors declare no conflict of interests.

\section{REFERENCES}

1. Mittur A. Piribedil: Antiparkinsonian properties and potential clinical utility in dopaminergic disorders. Curr Drug Ther 2011;6(1):17-34.

2. Piribedil. European chemicals agency; 2020.

3. Duffy EP. Stability of levothyroxine sodium products. Office of New Drug Quality Assessment; 2005.

4. United States Pharmacopeia/National Formulary, 43rd ed. U.S. Pharmacopeial Convention, Rockville; 2020.

5. European Pharmacopeia. European Directorate for Quality of Medicines. 10th ed. France; 2020.

6. Rohith KBV, Ramana VG, Latha MN, Supriya P, Harini U, Pawar AKM. Development and validation of stability indicating reverse phase high-performance liquid chromatographic method for the estimation of piribedil in bulk drug. Asian J Pharm Clin Res 2016;9:342-6.

7. Ibrahim H. Chemically modified carbon paste electrode for the potentiometric flow injection analysis of piribedil in pharmaceutical preparation and urine. J Pharm Biomed Anal 2005;38(4):624-32.

8. Issa YM, Hassouna MM, Abdel-Gawad FM, Hussien EM. Poly (vinyl chloride) ion-selective electrodes for Piribedil determination. J Pharm Biomed Anal 2000;23(2-3):493-502.

9. Sarati S, Guiso G, Spinelli R, Caccia S. Determination of piribedil and its basic metabolites in plasma by highperformance liquid chromatography. J Chromatogr 1991;563(2):323-32.

10. Uppuluri CT, DalviAV, Bommireddy EP, Ravi PR. Development and validation of rapid and sensitive LC methods with PDA and fluorescence detection for determination of piribedil in rat plasma and brain tissues and their pharmacokinetic application. Biomed Chromatogr 2018;32(10):e4303.

11. Yardımcı C, Süslü İ, Özaltın N. Determination of piribedil in pharmaceutical formulations by micellar electrokinetic capillary chromatography. Anal Bioanal Chem 2004;379(2):308-11.

12. Demirel M, Buyukkoroglu G, Kalava BS, Yazan Y. Enhancement in dissolution pattern of piribedil by molecular encapsulation with beta-cyclodextrin. Methods Find Exp Clin Pharmacol 2006;28(2):83-8.

13. Çelik B, Özdemir S, Barla Demirkoz A, Üner M. Optimization of piribedil mucoadhesive tablets for efficient therapy of Parkinson's disease: Physical characterization and ex vivo drug permeation through buccal mucosa. Drug Dev Ind Pharm 2017;43(11):1836-45.

14. Çelik B, Üner M. Formulation and characterization of Piribedil buccal tablets. $9^{\text {th }}$ Annual European Pharma Congress. Madrid: Spain; 2017.

15. Demirel M, Yazan Y, Müller RH, Kilic FA, Bozan B. Formulation and in vitro-in vivo evaluation of piribedil solid lipid micro- and nanoparticles. J Microencapsul 2001;18(3):359-71.

16. Mohan TS, Varma DP, Bhavyasri K, Prasad K, Mukkanti K, Jogia HA. Development and validation of piribedil in tablet dosage form by HPLC: A QbD and OFAT approach. Asian J Chem 2017;29 (5):1113-18.

17. Kumar N, Sangeetha D. Analytical method development by using QbD-An emerging approach for robust analytical method development. J Pharm Sci Res 2020;12(10):1298-305.

18. Validation of Analytical Procedures: Text and methodology, Proceedings of the International Conference on Harmonization. ICH, Q2 (R1), Harmonized Tripartite Guideline. Geneva; 1998. 